\title{
A floresta das adivinhas' ... ou os meandros da interacção social entre as crianças no jardim de infância em torno dos livros ilustrados
}

Resumo: Com base num episódio interactivo retirado das notas de campo do trabalho etnográfico realizado com um grupo de 10 crianças entre os 5 e os 6 anos de idade, em contexto de jardim de infância (II), este artigo mobiliza contributos da Sociologia da Infância para dar conta dos usos sociais que as crianças fazem dos livros ilustrados, quando os utilizam por iniciativa própria, e dos modos como i) evidenciam a sua agência na construção de uma identidade social no e do grupo; ii) ressignificam simbolicamente os livros ilustrados, objectos da produção cultural adulta destinada às crianças; iii) são usados simbólica e estrategicamente nas relações de poder e sociabilidade que no seu seio se jogam. Ao redefinir o livro ilustrado como objecto de uso por parte das crianças, visa-se contribuir para a consciencialização da necessidade de i) reavaliar o papel do livro no quotidiano dos tempos e espaços do Jl; ii) reavaliar as práticas de uso do livro ilustrado com crianças, em contexto institucional; iii) reconfigurar o livro como objecto cultural produtor de sentidos intersubjectivos; iv) reconfigurar o livro ilustrado como objecto de transacções sociais e apropriações culturais por parte das crianças que o usam, no grupo de pares; e, finalmente, v) rever as concepções de infância que presidem à escolha e selecção dos materiais impressos que são disponibilizados para uso das crianças.

Palavras-Chave: Jardim de infância; interacção social; literatura.

I Título de um poema de Manuel António Pina, in O TEPLUQUÊ, A Regra do Jogo, Porto, 1976. As diversas estrofes que aparecem ao longo do texto pertencem a este poema embora nem sempre pela ordem original.

2 Doutoranda do IV Programa de Doutoramento em Ciências da Educação da Faculdade de Psicologia e Ciências da Educação da Universidade do Porto, Portugal, 2005-2009.

3 Professora Auxiliar da Faculdade de Psicologia e Ciências da Educação da Universidade do Porto, Portugal. 


\title{
A forest of guesswork ... or the intricacies of social interaction between children in kindergarten around the picture books
}

\begin{abstract}
Based on an interactive episode taken from the field notes of fieldwork with a group of 10 children between 5 and 6 years old, in the context of kindergarten (JI), this article mobilizes contributions Sociology of Childhood to account for the social uses children make picture books when used on its own initiative, and the ways in which i) demonstrate your agency in the construction of social identity in the group and ii) their meaning symbolically illustrated books, objects of cultural production for adult children; iii) are used strategically and symbolic power relations and sociability that is playing in her womb. To redefine the picture book as an object for use by children, we aim to contribute to the awareness of the need to i) reassess the role of the book in time and space of everyday JI ii) reassess the practice of using illustrated book with children in institutional context; iii) reconfigure the book as a cultural object producer intersubjective meanings iv) reconfigure the illustrated book as an object of social transactions and cultural appropriation by children who use it, the peer group, and finally $v$ ) review the conceptions of childhood that underpin the choice and selection of printed materials that are available for children's use.

Key Words: Kindergarten; social interaction; literature.
\end{abstract}


uma altura em que a edição do livro para crianças atingiu números nunca antes imaginados ${ }^{4}$; em que a oferta é tão (ou mais) diversificada como a procura e as concepções de infância projectadas nos livros a ela dirigidos igualmente as mais diversas; em que inumeráveis títulos saem todos os dias dos armazéns das editoras e se expõem nas prateleiras de livrarias e bibliotecas; em que os autores e ilustradores se auto-legitimam numa produção cultural adulta para a infância; em que os prémios $^{5}$ e publicações se sucedem a um ritmo alucinante; as iniciativas das bibliotecas, das escolas e das políticas educativas, sobretudo as que visam promover as competências da literacia das crianças, expandem-se em convergência de interesses, contribuindo significativamente para um incremento impensável, há alguns anos, ao nível da edição do livro para crianças.

Numa altura destas, cabe então interrogar: o que fazem afinal as crianças pequenas com os livros que para elas se editam? Que papel tem nas suas vidas esse objecto simbólico, outrora sagrado, num tempo em que a institucionalização é marca constitutiva da infância? (Sarmento, 2004) Como tiram sentido dos livros e o transaccionam no grupo de pares, as crianças do JI? Para que servem os livros nas suas relações sociais privilegiadas, que função simbólica de objecto de prestígio e poder tem o livro nas relações entre pares? Que significado atribuem, no concreto, as crianças a cada livro que lhes é disponibilizado? Até aqui, e tanto quanto se sabe, os livros para crianças têm sido estudados pelos adultos como objectos da produção cultural adulta dirigida às crianças, mas sem que a vez e a vOz das crianças sejam tidas em conta. Os adultos colocam-se, invariavelmente, numa posição superior de olhar sobre os livros e sobre as crianças, distanciados das práticas de uso, apropriação e ressignificação dos livros por parte destas, a quem os dirigem. Mais do que saber o quê e o porquê do que os adultos produzem para elas, interessa então saber o que as crianças fazem com os livros que os adultos lhes dispõem.

\footnotetext{
4 Até à data, porém, nem a Associação de Editores e Livreiros nem o Instituto Português do Livro e das Bibliotecas nem o Observatório das Actividades Culturais ou a Biblioteca Nacional dispõem de dados estatísticos específicos relativos a este sector da produção editorial, o que impede a percepção objectiva da dimensão do fenómeno editorial dos livros para crianças. Recentemente, dados do jornal o Público, de 2 de Agosto de 2007 anunciavam que a Walt Disney Productions detém o maior número de traduções a nível mundial, o que dá conta de uma disneyzação global do mercado do livro para a infância, mas nem por isso uma medida da variedade editorial que concorre com esta hegemonia cultural de origem americana, particularmente em Portugal.

5 Desde o Prémio Hans Christian Andersen, instituído em 1956 e conhecido como o "Nobel" da Literatura para Crianças, com um prémio especial para ilustração desde 1966, à "Maçã de Ouro de Bratislava", Prémio da Bienal de llustração de Bratislava, instituído em 1967, ou o mais recente Prémio da Bienal Internacional de llustração para a Infância, Ilustrarte, inaugurada em 2003, no Barreiro (Portugal), entre tantos outros.
} 
Tomadas invariavelmente como leitoras dependentes da voz adulta, as crianças entre os 4 - 6 anos de idade são ainda assim, elas próprias, leitoras dos livros ilustrados. Revisitando-os, sozinhas ou em grupo, as crianças destas idades gastam tempo, por sua própria iniciativa, em volta dos $\operatorname{livros}^{6}$. O que neles as atrai? O que pensam e aprendem as crianças com os livros, o que ensinam umas às outras; as experiências que partilham e, sobretudo, os usos que dele fazem umas em relação às outras foi o que se tentou averiguar. Com base num exemplo etnográfico, procura-se dar conta do que as crianças fazem com os livros quando, entre si, no uso por sua iniciativa do livro ilustrado, decidem fazer uso dos livros existentes na sala do JI. Em particular, pretende-se desafiar-se as concepções dominantes e adultocêntricas acerca do livro. A partir deste, questionam-se as suas funções sociais, o que conta como leitura e a noção de criança não leitora e, finalmente, a ideia de grupo de pares como entidade homogénea.

6 A etnografia realizada mostra que as crianças podem gastar entre cinco a trinta e cinco minutos em volta dos livros. O tempo médio de uso do livro por sua iniciativa, ainda calculado de forma não absolutamente rigorosa, situa-se algures entre os dez e os quinze minutos, ocorrendo frequentemente mais do que uma vez por dia. 


\section{Fundamentação teórica}

Tendo por base os pressupostos da Sociologia da Infância (James, Jenks \& Prout, 1998), designadamente que i) a infância é uma construção sócio-histórica em processo e, portanto, fenómeno não universal, mas plural nos seus modos de agência, porque dependente dos contextos histórico-culturais e das matrizes sócio-económicas em que se inscreve; ii) as crianças são entendidas como actores sociais, o que implica estudá-las a partir de si próprias, desafiando as noções dominantes quer de infância quer de adultez; iii) a denúncia sócio-política da infância como grupo minoritário a define como grupo identitário, inserido na dupla estrutura patriarcal e adulta, cujas culturas e modos de participação devem ser valorizados; mas abraçando desde já os reposicionamentos teóricos que assumem a infância como fenómeno complexo, ambíguo e instável (Prout, 2002, 2004; James \& James, 2004) procurou-se estar com (Vasconcelos, 2000) as crianças, olhando-as como agentes activos na construção das rotinas instituintes do JI e como agentes socializadores das outras crianças bem como dos adultos presentes. Isto significa que em relação às noções dominantes de infância se procura ver para lá do visível, indagando os significados das acções das crianças e inscrevendo-as nos contextos sociais de interacção em que comparticipam no JI.

Partilhando com Corsaro (1985, 1993, 2002, 2005, Corsaro \& Miller, 1992) a noção de reprodução interpretativa, procura-se dar conta dos modos como, no uso do livro ilustrado por sua iniciativa, em contexto de jardim de infância, as crianças produzem e reproduzem acções transaccionando sentidos entre si, traduzindo, de forma paradigmática, a complexidade e densidade das relações sociais que as crianças estabelecem no grupo de pares. As culturas de pares permitem, neste contexto, relevar da importância das culturas da infância, estabelecendo-se estas como um conjunto de actividades ou rotinas, artefactos, valores ou preocupações que as crianças produzem e partilham na interacção com os seus pares (Corsaro, 2005: 110). Os aspectos reprodutivos e interpretativos das culturas da infância serão aqui observados em torno dos objectos culturais simbólicos que são os livros ilustrados.

Ora, se a reinterpretação activa pelas crianças desses produtos culturais (Sarmento, 2004: 18) se realiza a nível local, e se a globalização do mercado cria a ideia de uma infância única no espaço do mundo, a verdade é que os mesmos produtos culturais assumem propriedades e funções diversas numa utilização simbólica redefinida nas culturas de pares (cf. ibidem). As redes de sociabilidade específicas, as apropriações e ressignificações simbólicas dos livros para a infância tomam visibilidade na sua manipulação concreta pelas crianças, nos seus espaços de institucionalização.

Visto assim, o uso do livro por iniciativa própria entre crianças de um grupo de pares possui uma dimensão relacional constitutiva das culturas da infância, onde a interactividade, a ludicidade, a 
fantasia do real e a reiteração são eixos estruturantes (Sarmento, 2004). Acrescentamos-lhe ainda a corporeidade, que assume uma pregnância relevante muitas vezes ignorada e que é marca distintiva da acção das crianças.

Este conjunto de pressupostos teóricos é ainda inspirado pela etnometodologia (Garfinkel, 1967, Lapassade, 1996) - cujo estudo das actividades rotineiras, pelas quais passamos muitas vezes sem lhes prestar atenção, procura mostrar como os membros de uma dada comunidade procedem de modo inteligente, coerente e lógico, estruturando através das práticas sociais formas de organização e entendimento do grupo, nelas incorporando as estruturas sociais instituintes numa ordem social que resulta instituída (cf, Ferreira, 2004: 29) - e escorado também no interaccionismo simbólico (Goffman, 1959/1993, Denzin, 1998, Lapassade, 1996), assumindo que toda a interacção é dotada de um significado mencionado pelos actores e por eles sucessivamente interpretado e (re)negociado. Assim, pretende-se desvendar os significados transaccionados pelas crianças durante um episódio interactivo em volta dos livros, as negociações por elas efectuadas nos modos de definição e sucessiva redefinição da situação interactiva. Colocados num paradigma sociológico interpretativo crítico, onde os aspectos sociais de origem das crianças são tidos como importantes, também, nas suas acções, procura-se descrevê-las, compreendê-las e seguidamente interpretá-las no intuito de revelar as dimensões intersubjectivas geradas e geradoras da/na acção das crianças (Ferreira, 2004:29), que sabemos membros competentes de um grupo social que elas próprias se encarregam de (re)estruturar permanentemente em relação e na relação com a estrutura organizada da ordem social instituída do JI.

Cabe ainda explicitar que se está a lidar com crianças e não com a criança, essa entidade semiabstracta, que representa aquilo que se julga ser o comum entre as crianças de uma mesma idade, género, meio social ou outra variável da análise social. Não trataremos de uma criança média colaborando para a construção desse indicador quer as concepções médico-psicológicas quer a estatística -, aquela que no essencial permite designar, numa economia de meios em termos de construção social, as crianças em causa, mas as crianças concretas com quem se partilhou experiência no JI. Assim, a criança de 5-6 anos, que não domina a leitura das letras, é apenas essa entidade não real que se concretiza, aqui, nas crianças do JI observado e contribui para a reiteração da pluralidade e heterogeneidade do designado grupo de pares.

\section{Acerca do conceito de criança não leitora}

No JI, lugar de institucionalização dos mais pequenos, as crianças não sabem (salvo casos absolutamente excepcionais) ler as letras e, por tal, dependem de outros para se apropriarem do 
conteúdo verbal dos livros ilustrados. No entanto, esta dependência da criança que ainda não decifra o código escrito não faz dela um invisual da sociedade letrada. A criança aprende, desde o nascimento, a ler o mundo: o bebé aprende a ler a expressão facial dos que o circundam, o tom de voz com que lhe falam, o modo como o tocam, e não apenas lê como rapidamente aprende a interpretar esses sinais em função do contexto de socialização em que se desenvolve e seus actores.

A questão básica do dualismo entre dependência e autonomia, nas concepções da infância, revela-se também no âmbito desta problemática. Definindo a criança como não leitora enfatiza-se o aspecto de deficit em relação ao adulto (assumido o estado adulto completo, nas sociedades ocidentais, como alfabetizado). Uma tal concepção de infância é consonante com visões que consideram as crianças como culturalmente ignorantes, moralmente irresponsáveis e socialmente incompetentes (cf. Leonard, 1991). Esquecem-se, assim, as competências leitoras não estritamente condicionadas à descodificação de um código escrito.

A valorização social da passagem, claramente ritualizada ${ }^{7}$, do estado de dependência para o estado de autonomia que a aprendizagem da leitura e da escrita comporta, faz da palavra escrita uma hegemonia visual quase inabalável ${ }^{8}$ e inscreve-se no carácter paradoxal como elas [crianças] são consideradas pela sociedade "dos adultos" (Sarmento, 1997: 11): espera-se que sejam dependentes quando os adultos preferem a dependência, mas deseja-se que tenham um comportamento autónomo (Calvert, cit. in Sarmento, op.cit.: 13). Depois de aprender a ler as letras, seria preciso voltar a aprender a ver, sem ver o que esses traços negros desenhados nos forçam a ver, para podermos retornar ao estado de independência (independência não significa inocência) da criança que não sabe ler as letras. Tudo, para nós, adultos alfabetizados, parece trazer letras penduradas e deveríamos antes de mais lamentar a nossa distracção de letrados, a cegueira a que nos confina a cidadania das letras (Torrado, 2002:31).

É nesta perspectiva que se pretende olhar para os livros ilustrados de hoje e para a sua utilização por parte das crianças. Nos modernos livros para a infância, onde a ilustração se tornou autónoma, por vezes até mesmo incómoda, e passou a ser não uma explicação ou esclarecimento do texto, mas um outro texto, a imagem assume um novo estatuto que lhe permite que se constitua como uma forma de valorização formal, de sedução sobre o leitor e de estímulo ao pensamento visual (Maia, 2003/2005: 116). A presença da imagem constitui um novo texto. Em vez de o simplificar ela complexifica-o. O texto verbal é desafiado na sua ambiguidade pelo novo texto visual, requerendo do leitor um trabalho de imaginação superlativo. Trata-se de jogar o jogo da imaginação com dois textos,

\footnotetext{
7 As "festas de finalistas" instituídas nos Jl e a dimensão que tal fenómeno vem assumindo nas últimas décadas são disso exemplo.

8 Veja-se o conhecido efeito de Stroop, que demonstra como, para um leitor médio é mais difícil dizer a cor em que estão escritas as palavras, elas próprias nomes de cor, se houver uma incongruência entre a cor e a palavra escrita (Castro, 2000: I 4 I)
} 
de explorar todas as combinações possíveis entre texto verbal e texto visual, de ler duplamente. A memória do texto verbal, que outrora lhe foi lido, na presença da imagem que se the associa, serve de ponto de partida para a criança jogar este jogo da imaginação. A sua dependência, quando ainda não sabe ler as letras, não é senão muito relativa e parcial: a criança é autónoma na sua leitura para lá das letras e é dessa autonomia que é preciso falar.

Quem diz que se pode pensar muito e que os pensamentos não ocupam lugar de certeza que nunca pensou muito no assunto se não também acabava por rebentar... Manuel António Pina

Metodologia

A situação de interacção social em torno do livro ilustrado que se analisa neste texto refere-se a um grupo de 10 crianças $^{9}$ de meio urbano que tinham, no início do trabalho ${ }^{10}$, entre os 4 anos e 1 mês e os 5 anos, maioritariamente provenientes de famílias com graus académicos superiores (das 10 crianças, apenas 3 eram filhas de pais com o $12^{\circ}$ ano), tendo metade frequentado desde o berçário este JI da rede privada. As restantes tinham entrado para o JI ao longo dos dois anos seguintes, o que significa que nenhuma delas o estava a frequentar pela primeira vez, quando as conheci e com elas partilhei o quotidiano institucional.

O trabalho de campo consistiu em estar com (Vasconcelos, 2000) as crianças, em interacção face a face (Goffman, 1974), procurando observar, participar, mantendo uma posição periférica e sempre o mais possível reactiva (Corsaro, 1985, 2005; Corsaro \& Molinari, 1990). Não foram usados quaisquer artefactos tecnológicos de registo de som ou de imagem, além de um caderno de notas e de um lápis. O nível de densidade das descrições (Geertz, 1973) foi indissociável da minha longa convivência com as crianças e das relações que com elas desenvolvi ao longo do trabalho de campo.

9 Embora num total de 15 crianças, o grupo nuclear estável acompanhado durante todo o período de trabalho de campo, era constituído por 7 meninas e 3 rapazes. 10 A etnografia foi levada a cabo por Cristina Madureira e realizou-se entre Janeiro de 2006 e Junho de 2007 


\section{Afloresta das adivinhas, uma aventura em três modos e alguns momentos}

A entrada na chamada idade "pré-escolar" e as pressões sociais (familiares em primeira mão, mas de um modo mais geral partilhadas por toda a sociedade) para a aprendizagem da leitura e da escrita enformam (e informam) um novo modo de usar os livros. Essas pressões começam, primeiramente, por estar presentes na organização do espaço da sala do JI. Antevêem-se, nesta organização prévia do espaço pelo adulto, implicações mais ou menos visíveis no uso dos tempos, espaços e materiais das e para as crianças, e suas significações, uma vez que tanto podem constranger como possibilitar o estabelecimento de determinadas relações por parte de adultos e crianças face ao livro.

Modo I - A rotina instituída pela educadora: o tempo, o espaço e o uso dos livros

O ano pré-escolar das crianças com quem vivi no JI foi um ano particularmente interessante e rico em experiência em torno dos livros ${ }^{11}$. Além de algumas actividades propostas extemporaneamente, a educadora instituiu, logo no início do ano, o "momento de leitura partilhada pelo grupo", a ter lugar, invariavelmente, antes do almoço, sendo-lhe reservado um período de cerca de 20 minutos. A escolha dos livros a ler era feita pelas crianças, uma em cada dia, a seu pedido, tendo no final do ano, chegado a ser preciso fazer uma lista para que todos pudessem ter a sua vez, sem conflitos. Sentados todos na manta, em roda, a educadora tomava o livro escolhido na mão e lia-o ao grupo. Os modos de contar da educadora foram tomando diversas formas ao longo do ano ${ }^{12}$, mas no essencial a rotina da leitura diária partilhada por todos institucionalizou-se.

Para os livros, o adulto criara a biblioteca, um espaço localizado na sala de actividades com um expositor de livros ${ }^{13}$ colocado na parede à altura das crianças, dois pequenos sofás à esquerda e duas cadeiras, em frente, do lado direito, sendo delimitado por uma manta e um pequeno móvel. Este espaço era utilizado pelas crianças maioritariamente para o uso de livros e jogos de tabuleiro. Aliás,

\footnotetext{
II Num texto final que a educadora criou para as crianças representarem na festa de finalistas, em Junho, o percurso institucional do grupo era revisitado e este último ano fol designado "o ano dos livros".

12 Este aspecto foi muito significativo nos modos de estar das crianças durante a leitura, embora não se trate do uso livro por iniciativa própria parte das crianças. Por esse motivo não será aqui desenvolvido.

130 expositor, contrariamente, à estante, permite colocar os livros com a capa visível, o que facilita o acesso e as escolhas das crianças.
} 
foram estas duas actividades que dominaram, no primeiro período escolar, as actividades não orientadas das crianças, a par com os desenhos e alguns trabalhos de mesa. O lugar dos livros foi sempre e invariavelmente a biblioteca. Nunca os livros figuraram em outros lugares que o expositor que lhes era destinado. Mais, livros fora da biblioteca eram considerados livros desarrumados e, portanto, rapidamente, devolvidos ao seu nicho, quer pela mão da educadora quer pela das crianças, sob o controle adulto.

Esta limitação do uso dos livros ao espaço da biblioteca teve consequências evidentes ao nível do uso dos livros por parte das crianças, uma vez que instituía um uso segregado do livro em relação às outras actividades, nomeadamente as de carácter não orientado fora do espaço instituído como dos livros. Com esta organização do espaço e tempo dos livros, o adulto veiculava um valor de uso do livro circunscrito a um tempo e um espaço autónomos, que não se confundia nem podia imiscuir-se em outras actividades. Este facto tem implicações pedagógicas e atribui valores sociais de uso do livro que o colocam, desde logo, numa esfera exclusiva de utilização académica ou de serviço cultural (a biblioteca), mas não na esfera doméstica. O carácter privado do uso do livro excluía-se assim dos pressupostos pedagógicos do adulto que organizava o espaço da educação de infância. Mais, assumia-se o lugar e o tempo dos livros como especializado, sacralizado (os livros não podem andar por aí por qualquer lado, em qualquer momento) e institucionalizado. Ou seja, os livros não eram brinquedos. Os livros tinham um estatuto próprio, à margem dos tempos e lugares das brincadeiras. Esta assunção do valor estatutário particular do livro reflectiu-se, inevitavelmente, nos usos, apropriações e ressignificações do objecto por parte das crianças ${ }^{14}$.

A Sara também gostava muito das árvores mas não queria ficar ali para sempre a arborizar! Antes queria ficar menina e falar e andar e ter as pernas para saltar. Manuel António Pina

Modo 2 - Os livros para crianças e as concepções da infância da educadora: valores simbólicos e de uso implícitos na escolha dos livros da sala do jardim de infância

Do ponto de vista sociológico, é essencial perceber que os livros para crianças representam um modelo do que os adultos pensam ou desejam dever ser a infância (Hunt, 2004: 40). Postas as coisas nestes termos, os livros que figuram na sala do JI permitem inferir, até certo ponto, o que o adulto pensa ser a infância e, mais concretamente, qual a sua concepção de infância e de criança.

14 É de referir que as crianças contornaram uma vez por outra esta limitação usando uns pequenos diários, colocados pela educadora no espaço da casinha, como sendo livros e atribuindo-lhes um valor de uso muito distinto do habitual. Nomeadamente, os rapazes usaram-nos para provocar as raparigas, pelo simples facto de se apoderarem deles. As crianças referiam-se a estes diários (na realidade, pequenos cadernos de capas duras) como livros. O mesmo acontecia em relação ao caderno de notas da etnógrafa, também de capas duras, designado invariavelmente por o livro da Cristina. 
Nesta biblioteca havia livros informativos ${ }^{15}$, livros de histórias, incluindo os contos de fadas, livros de adivinhas ${ }^{16}$ e um livro de alfabeto. Há ainda a referir a presença de livros de adivinhas artesanais realizados pelas crianças. Nesta diversidade de géneros de livros para a infância podemos identificar as valências implícitas de cada um, descortinando assim um currículo oculto materializado na selecção bibliográfica do adulto: os livros informativos apelando ao conhecimento do real, os livros de histórias à fantasia e à imaginação, os livros de adivinhas ao desenvolvimento do raciocínio lógico-dedutivo, da memória e da dinâmica interactiva pergunta-resposta ${ }^{17}$ e o livro de alfabeto prenunciando a aprendizagem das letras.

Releva daqui a constatação de uma heterogeneidade de critérios que presidem à escolha dos livros pelo adulto para figurarem na sala do JI, tendo em conta a concepção da educadora da criança de 5-6 anos.

Nos "momentos de leitura partilhada pelo grupo", era habitual os livros serem escolhidos pelas crianças, escolha essa variada a ponto de praticamente todos os livros da sala terem sido lidos pela educadora.

A educadora, enquanto adulto, optou por colocar ao dispor das crianças uma selecção não homogénea de livros que foram usados nos tempos das e para as crianças ao sabor das preferências do grupo. Não parecia haver, da sua parte, nem nas leituras que fez nem no tipo de livros disponibilizados, uma instrumentalização ou utilização didáctica dos livros. Deste ponto de vista, os livros aparecem nesta sala o mais libertos possível de prévias conotações simbólicas ou valor de uso pré-definidos. Ainda assim, essas conotações e valores de uso são construídas pelo adulto e pelas crianças ao longo do tempo e do espaço que partilham, no modo como cada um usa os livros. Como ficou dito atrás, os livros tinham o seu nicho próprio, as regras de uso incluindo as de arrumação estavam instituídas e as crianças moviam-se nessa configuração do espaço e do tempo desenhada em torno dos livros.

$\mathrm{Na}$ procura de algum critério ou conjunto de critérios que representassem as escolhas da educadora, apenas se conseguiu verificar i) um respeito particular pelas produções das crianças, acompanhando-as os livros por elas produzidos no seu percurso institucional; ii) aceitação sem condições de todos os livros oferecidos pelas crianças ${ }^{18}$; iii) apropriação de alguns livros da biblioteca do grupo que deixara a sala (ou classe) no ano anterior - nomeadamente no caso dos livros da

15 A classificação dos livros é um assunto complexo e as categorias são muitas vezes sobreponíveis. Nomeadamente, no que refere aos livros informativos acontece muitos deles serem concebidos sob a forma de história, ainda que o seu conteúdo tenha inequivocamente um objectivo instrutivo.

16 Concretamente, três livros de adivinhas: "Quando crescer quero ser..." e "Animais e muito mais...", ambos da autoria de Maria Lúcia Carvalho, com ilustrações de Raquel Pinheiro (ambos da colecção Montanha Mágica, Editora Everest, 2004) e "Adivinha, adivinha" recolha e selecção de Luísa Ducla Soares, com ilustrações de Sofia Castro (Livros Horizonte, 2001).

17 Muito particularmente enfatizando-se o facto de que só há uma resposta certa para cada pergunto.

18 Grande parte dos livros do espólio do Jl é proveniente de ofertas das próprias crianças e suas famílias, oferta feita quer ao longo do ano quer no final do ano (refira-se um caso paradigmático que revela como os livros, na concepção das famílias, parecem deixar de servir às crianças, tal e qual como a roupa). 
adivinhas ${ }^{19}$; iv) substituição de alguns livros mais “infantis" por livros de histórias mais complexas, ainda que com manutenção de alguns livros do ano anterior; v) inclusão de alguns livros especificamente dirigidos à faixa etária do último ano de JI, como os livros de alfabeto.

\section{Os livros de adivinhas}

Mas é apenas dos livros de adivinhas que vamos tratar. Desses, havia dois tipos. O livro "Animais e muito mais..." - presente no episódio interactivo que se analisará - um livro de estrutura simples com i) corpo central da adivinha em verso rimado sobre fundo colorido plano; ii) onomatopeia referente ao animal em causa e fórmula de conclusão, de apelo à resposta ("Agora vais adivinhar/Antes da página voltar...”), inscritas na silhueta a branco do animal; iii) resposta (nome do animal) aposto à respectiva imagem sobreposta à sua silhueta branca (evocativa da página anterior); iv) ícone representativo do animal repetido em forma de padrão e fórmula de apelo à adivinha seguinte inscrita na parte inferior da página ("E agora a seguir,/o que estará para vir?). Na contracapa, anuncia-se: "Um livro em forma de jogo, tornando a leitura uma actividade divertida. Rimas e curiosidades sobre o mundo fascinante dos animais, com ilustrações que põem à prova a capacidade de observação dos mais pequeninos. E agora vais abrir, para os animais descobrir..."

Esta mensagem, habilmente destinada de forma ambivalente às crianças e aos adultos, revela uma concepção de infância como o tempo do jogo e das actividades divertidas (uma forma, provavelmente, de evocar o brincar) em que a leitura se integrará de forma "natural" e em que as ilustrações contribuem igualmente para o desenvolvimento das capacidades da criança. Ora, a estrutura do livro, quer em matéria de texto quer de imagens, pressupõe ou uma criança muito pequena ou uma criança, se um pouco mais velha, pouco capaz. Os textos são tão óbvios e as imagens corroboram-nos de tal modo que as respostas às adivinhas são inequivocamente evidentes. A onomatopeia que precede a fórmula de conclusão, secundada pela silhueta do animal, desvela a solução de um enigma já de si pouco elaborado. Após algumas leituras apenas, nos "momento de leitura partilhada pelo grupo", as crianças rapidamente decoraram as adivinhas e os bordões da estrutura do livro, bem como a sua própria sequência.

Contrariamente a este exemplo, o livro "Adivinha, adivinha!" assume uma concepção de infância muito diferente. $\mathrm{O}$ texto da contracapa é elucidativo dos pressupostos que presidem à sua elaboração.

19 É o caso do livro "Adivinha, adivinha", objecto central do episódio que se analisará. 
"Há milhares de anos que existem adivinhas, que têm feito pensar e rir muitas gerações de adultos e crianças. Já se perdeu a memória de quem as inventou, e são hoje um tesouro da nossa cultura, que nunca pára de crescer porque há sempre gente imaginativa que o vai acrescentando.

Escolhemos para vocês estas I 50 adivinhas, que se referem a coisas que todos conhecem, para que descubram a solução sem o auxílio dos mais crescidos.

Leiam com atenção, puxem pela cabeça, vejam se acertam.

Mas o prazer das adivinhas não acaba aí. Foram feitas para andar de boca em boca, no recreio, em casa, na rua. Divirtam-se, intrigando com elas os vossos amigos, os irmãos, os pais, os avós.

E quem sabe, afinal, quantas adivinhas serão vocês próprios capazes de inventar.

Os desenhos ilustram as soluções de muitas adivinhas mas, para ser mais divertido, não estão na mesma página."

Em primeiro lugar, este texto inscreve as adivinhas num contexto cultural e histórico humano com apelo à continuidade da reprodução e produção de um património considerado valioso. Depois, revela que o livro se destina a crianças leitoras, no sentido amplo do termo, que se desejam autónomas, capazes de pensar por si e capazes de esforço e, no entanto, de se divertirem e de divertirem os outros. Finalmente, o texto jogará às adivinhas também com as imagens duplicando o divertimento e a dificuldade de chegada à solução. Organizadas em nove títulos (natureza, animais, corpo humano, alimentos, objectos, diferenças e semelhanças, para quem souber ler ${ }^{20}$, problemas e diversas) as adivinhas recolhidas e seleccionadas ${ }^{21}$ estão numeradas e as suas soluções são apresentadas em forma de índice no final do livro ${ }^{22}$.

Das várias vezes que a educadora leu este livro no "momento de leitura partilhada pelo grupo", ela própria recorreu às soluções para poder ajudar as crianças na conquista da resposta certa.

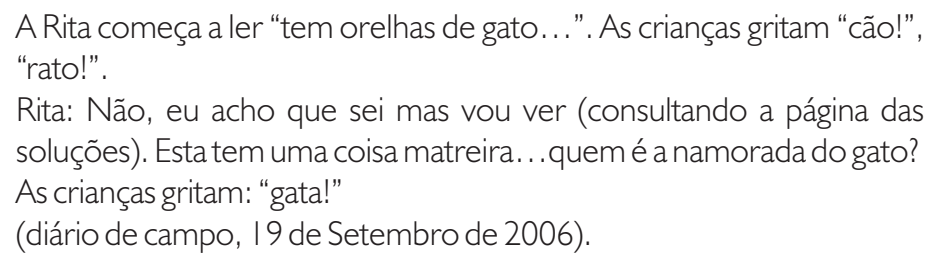

A instituição de um "momento de leitura partilhada pelo grupo" atribui, por si só, ao livro um significado simbólico de partilha diária pelo grupo, num momento e espaço consagrados a esse momento ritualizado. Qualquer dos livros atrás referidos foi lido diversas vezes às crianças, a seu

\footnotetext{
20 Infere-se daqui, e em conjunto com a mensagem da contracapa, a concepção da criança como leitora, a priori, com uma distinção apenas de quem souber ler, subentendendo-se, souber ler as letras, para este título especificamente.

21 Que incluem, à semelhança das variadas colecções não destinadas necessariamente a crianças mas simplesmente ao registo da tradição oral, textos que não são propriamente adivinhas. A este propósito cf. Nogueira, 2004.

22 "Porque uma adivinha perde a sua integridade se antecipadamente se souber o que se procura, pensamos que as soluções devem ser remetidas para um índice final, de forma a salvaguardar a essência do jogo, como, aliás, tem sido sugerido e praticado por vários autores." (Nogueira, 2004: 6)
} 
pedido, pela educadora, de um modo quase invariável. Sentada de pernas cruzadas entre as crianças, na roda, com o livro voltado para si, quase encostado ao peito, afastando-o apenas o suficiente para conseguir ler a adivinha, a Rita só voltava o livro para as crianças depois de estas terem acertado na solução.

Por várias vezes, como na citação acima, na necessidade de procurar a página das soluções para confirmar a resposta à adivinha formulada, o uso do livro por parte da educadora denunciou o seu desconhecimento prévio do conteúdo dos livros presentes na biblioteca da sala. A progressiva familiaridade com o livro fez com que, posteriormente, as imagens fossem deixadas à vista, uma vez que não correspondiam directamente às adivinhas daquelas páginas. As crianças, no entanto, não deixaram, até ao fim, de tentar a correspondência entre imagem e texto como estratégia de superação de dificuldade de acertar as respostas.

Acerca do conceito de adivinha

Definida teoricamente como um texto verbal curto que apela a uma resposta, contida na pergunta de modo cifrado ou encoberto (Nogueira, 2004: 2) a adivinha é uma forma verbal simples de tradição popular oral. Recorrendo à analogia como princípio constitutivo básico, a adivinha (...) apresenta uma linguagem próxima do mito e representa um processo elementar de conhecimento (Topa, 1998: 61). Tratando-se de um género literário de transmissão oral, a adivinha sucumbe de

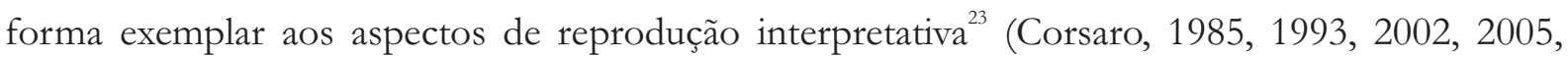
Corsaro \& Miller, 1992). Ao alcançar popularidade, a adivinha multiplica-se em textos coetâneos de autoria colectiva, num equilíbrio constante entre duas forças antagónicas: uma de fixação, que tende para o "imobilismo nuclear"; e outra de criatividade versátil, definida pelo "enriquecimento desse mesmo modelo, com ampliação das variantes até ao infinito" (Nogueira, op.cit.: 5, sublinhados nossos). Assim, as múltiplas variantes da mesma adivinha não são mais que embelezamentos (Corsaro, 2005) de um texto cujas origens dificilmente se identificam mas que mantém a sua estrutura básica.

A adivinha portuguesa parece conter, genericamente, uma fórmula de introdução, um corpo central e, eventualmente, uma fórmula de conclusão (cf. Nogueira, op.cit.: 2). As fórmulas de introdução - as mais comuns, “- Qualé a coisa qual é ela" e “- O que é, o que é” - permitem identificar de imediato o género de texto e lançar o jogo. Na realidade, a adivinha consiste num jogo verbal de

$23 \mathrm{O}$ conceito de reprodução interpretativa foi fundamental para romper com as teorias funcionalistas e da reprodução social, que informam, em particular, o conceito tradicional de socialização (Cf. Corsaro, 1997). 
revelação e obscurecimento do objecto ${ }^{24}$, que fornece uma definição, insinuante e engenhosa, de algo conhecido, mas dissimulando-o, de modo a não permitir a localização imediata do referente (Nogueira, idem). Assim, mais do que simples brinquedo verbal (Topa, 1998: 63) a adivinha é uma forma de designar as coisas conhecidas de um modo ambíguo, fazendo-as perderem a sua dimensão unívoca em favor da pulverização de sentidos, modificando radicalmente o conhecimento que o sujeito tem do universo (Nogueira, ib.: 8).

Em Portugal, existe um adivinhanceiro nacional, cujo registo escrito, ainda que não completo, se tem reunido em variadas obras, desde Passatempo Honesto de Enigmas e Adivinhações (1603), de Francisco Lopes às mais recentes Adivinhas Populares Portuguesas (2000) de Viale Moutinho, não tendo passado despercebido a etnógrafos como Teófilo Braga (1881) ou Augusto César Pires de Lima (1921). Quer pelo seu carácter lúdico quer arquetípico da cultura oral, as adivinhas parecem agradar desde sempre às camadas mais populares, às crianças e aos velhos. Não admira, portanto, que entre a produção editorial para a infância, se encontrem inúmeros títulos referentes ao adivinhanceiro popular. Paralelamente, alguns autores descobriram neste "tesouro sem dono" um mote para realizações mais ou menos inéditas, nem sempre da melhor qualidade literária nem dotadas do engenho popular, que apenas espelham concepções de infância muito indulgentes para com os sujeitos a quem se dirigem.

\section{Se dissesse que ia voltar para casa o Homem Mau dizia-Ihe que não, que ia ficar ali presa na Floresta e ela ficava mesmo porque não tinha adivinhado a adivinha. Manuel António Pina}

\section{Modo 3 - Nos meandros da floresta: um episódio interactivo entre crianças}

Face à organização da sala e à presença dos livros no espaço da biblioteca, a familiaridade das crianças com o material escrito sob a forma de livro era visível no modo como manipulavam o objecto e dominavam o léxico específico da produção impressa (página, capa, índice, título, texto, imagens, autor, ilustrações eram palavras de uso corrente entre o grupo).

Também as suas preferências se tornaram visíveis, quer nas escolhas que faziam nos "momentos de leitura partilhada pelo grupo" quer, precisamente, no uso do livro por iniciativa própria. As crianças mostraram-se selectivas quanto aos géneros de livros eleitos para a sua actividade. Os rapazes dedicando-se mais aos livros informativos - ou tratando os livros de outros

24 Geralmente, através do uso da comparação ou da metáfora. 
géneros numa perspectiva de recolha e debate de informação - e as meninas fazendo um uso intensivo (no primeiro período escolar) dos livros de adivinhas. Foi, exactamente, em torno destes que se verificaram as situações mais intensas, mais densas e também mais longas do ponto de vista da interacção social.

É da confluência desta familiaridade e selectividade que resulta a eleição privilegiada dos livros de adivinhas, distinguindo-os como género preferencial (pelo menos, transitoriamente) de entre todos os livros disponíveis. Isto releva dos modos não passivos de consumo dos livros pelas crianças. Não só as crianças distinguiam géneros e revelavam as suas preferências em cada momento, como pareciam identificar em cada género as potencialidades de acção neles inscritas. As crianças pareciam escolher os livros em função do tipo de interacção que pretendiam desencadear, quer com o objecto em si, quer com as outras crianças ou adultos presentes. Esta selectividade prática (não necessariamente racional ou consciente em todos os momentos) dá conta da agência das crianças nos usos, apropriações e ressignificações do livro ilustrado.

Foi no uso continuado dos livros de adivinhas que se tornaram visíveis distinções mais refinadas nos processos de selecção das crianças. Primeiro, a distinção que faziam entre os dois tipos de livro disponíveis.

Catarina: Agora vou contar adivinhas fáceis... (pegando no livro "Quando crescer...quero ser")

Segundo, nos modos como se foram apropriando da lógica interna do livro e delineando estratégias de domínio dessa lógica, particularmente no que refere ao livro das “adivinhas difíceis”, as crianças levaram algum tempo a perceber que de nada lhes adiantava espreitar as imagens para tentar conseguir a solução de forma mais rápida. As imagens traíam-nas, muitas vezes, na descoberta das soluções correctas. Mas nem sempre. Após várias leituras do livro, repetidas vezes escolhido pelas crianças, elas começaram a decorar quer as adivinhas quer as soluções e a memorizar as relações entre texto e imagens. Assim, encontraram o seu modo próprio de ler as adivinhas, por iniciativa própria, em grupo de pares.

Tendo-se observado diversas vezes o uso deste livro em momentos de actividade não orientada, nomeadamente entre as meninas, e dando-se conta dos aspectos de rotina que a utilização deste objecto assumia, torna-se pertinente analisar e compreender os aspectos que remetem para a reprodução vs. interpretação que as crianças faziam dele e do seu conteúdo, na relação entre pares, dos modos como iam embelezando (Corsaro, 2005) os procedimentos de rotina com pequenos detalhes que conferiam à interacção um duplo aspecto de suspense e surpresa, ou seja, 
reconfigurando-o sucessivamente na imprevisibilidade da repetição não exacta da rotina.

Vais-me prender, disse então a Sara, e o Homem Mau ficou muito atrapalhado com a resposta, porque se a aprendesse ela adivinhava e tinha que ir para casa, mas se fosse para casa não tinha adivinhado e devia ficar presa.

Pela floresta dentro... ou como as crianças jogam às adivinhas

O episódio interactivo (Corsaro, 1979b, 1985, 1993) que agora se apresenta ocorreu no dia 10 de Outubro de 2006, em momento de actividade livre das crianças, entre as 9h20m e as 9h55m, tendo portanto a duração de 35 minutos, um tempo excepcional na média dos episódios observados no uso dos livros pelas crianças, por iniciativa própria.

Trata-se de um episódio complexo, composto por vários momentos, em que se trata da reprodução interpretativa da leitura dos livros de adivinhas, nele se identificando diferentes elementos das culturas de pares, e de processos de recomposição do pequeno grupo de interacção social no cenário da biblioteca.

Participam nos momentos em análise a Susana, a Marta, a Catarina, a Margarida todas com 5 anos e alguns meses ${ }^{25}$ e ainda, extemporaneamente, o Guilherme com 4 anos e oito meses ${ }^{26}$. As variações de idade, ainda que já não muito significativas em si entre as crianças acabavam por ser compensadas, de algum modo, pela sua história institucional, ou seja, pelo seu conhecimento da instituição e do grupo, uma vez que, precisamente, eram as mais novas aquelas que frequentavam o JI desde os 4 meses de idade. Assim, os veteranos (como usou chamar-se) são a Margarida, a Marta e o Guilherme, enquanto as mais velhas mas novatas são a Catarina e a Susana. Ainda assim, porque já juntas há mais de dois anos, estas crianças dominam as rotinas do JI e os hábitos de grupo de maneira genericamente pouco desigual.

A adivinha ainda podia ter solução, mas a resposta da Sara é que não. E o Homem Mau pensava no assunto com toda a força que tinha a ver se adivinhava como resolver a resposta à adivinha. Manuel António Pina

25 A Susana era a mais velha com 5 anos e 10 meses e a Margarida, a mais nova, com 5 anos e 3 meses. 26 Embora o mais novo do grupo, o Guilherme frequentava o fl desde os 4 meses de idade. 


\begin{tabular}{|c|c|}
\hline 01 & $9 \mathrm{~h} 20 \mathrm{~m}$ \\
\hline 02 & Manel está na mesa a fazer um puzzle do Winnie the Pooh.. \\
\hline 03 & Catarina e a Susana estão na biblioteca, sentadas no sofá com a Margarida sentada \\
\hline 04 & numa cadeira, em frente. \\
\hline 05 & Catarina tem na mão o livro "Adivinha, Adivinha" e faz adivinhas à Margarida. \\
\hline 06 & A Marta está ao lado da Catarina com o livro "Animais e muito mais..." \\
\hline 07 & Catarina: Qual é a coisa que nós cosemos? \\
\hline 08 & Margarida: Botão! \\
\hline 09 & Catarina: Boa! Qual é a coisa que nós temos na boca?... Começa por "b"... Qual é a coisa \\
\hline 10 & que nós temos na boca com os dentes a cair? \\
\hline 11 & Margarida: Boca! \\
\hline 12 & Marta: Achas que a boca cai? \\
\hline 13 & Catarina: (virando o livro para a Margarida e apontando a imagem) Rebuçado! (voltando \\
\hline 14 & de novo o livro para si) Qual é a coisa com que escrevemos? \\
\hline 15 & $(\ldots)$ \\
\hline 16 & Catarina: Qual é a coisa que pomos as cartas?... (...) Que abrimos as portas?... \\
\hline 17 & Que metemos flores? (...) Que dormimos? (... ) Que pomos nos olhos?... Qual é a coisa \\
\hline 18 & que faz assim... (faz um gesto com o indicador para cima e para baixo) \\
\hline 19 & Susana: Uma coisa... (a Catarina tapa-Ihe a boca) \\
\hline 20 & Margarida: Pente! \\
\hline 21 & Catarina: Achas que isto é um pente?! (virando o livro para a Margarida e apontando com \\
\hline 22 & o dedo a imagem da letra "M") \\
\hline 23 & Susana: É um "m" de Margarida \\
\hline 24 & A Margarida passa para a frente da Marta que lhe faz as adivinhas do seu livro ${ }^{27}$ \\
\hline 25 & $\begin{array}{l}\text { [Após duas adivinhas e uma breve troca de palavras, a Marta passa o livro } \\
\text { à Margarida que segue com mais duas adivinhas] }\end{array}$ \\
\hline
\end{tabular}


O livro de adivinhas “Adivinha, adivinha!” é o objecto simbólico que começa por definir na díada das meninas os papéis de questionadora/questionada. A Catarina, na posse do livro, questiona a Margarida, sentada à sua frente, reproduzindo interpretativamente a prática da educadora no "momento de leitura partilhada": quem tem o livro toma a iniciativa de se dirigir e colocar a adivinha a outro/s a quem compete responder acertadamente; o livro mantém-se sempre voltado para si e, frequentemente, quase encostado ao peito, enquanto aguarda as respostas. As crianças que devem responder, não podem ver as imagens antes de acertarem a solução da adivinha e está nas mãos da questionadora determinar o momento e tempo de acesso das crianças às imagens, voltando o livro para elas.

Assim, a Catarina questiona a Margarida porque possui o livro e esse interrogatório é visto como legítimo porque se integra no cumprimento das regras do jogo: quem responde não pode ver as imagens antes de acertar a solução da adivinha e está nas mãos da questionadora determinar o momento e tempo de acesso do respondente às imagens, voltando o livro para ela. A Margarida responde porque, para além de não possuir o livro, a sua intervenção é indispensável para a concretização do jogo.

A Marta e a Susana estão em posições privilegiadas, exteriores à díada, pois podem ver as imagens do livro que a Catarina tem na mão e, assim, supostamente, ter acesso às soluções de uma forma considerada como ilegítima no grupo, tal como reitera a acção da Catarina (linha 28) quando tapa a boca à Susana. Sendo aceitável que a Catarina dê pistas à Margarida, ainda que a induzam em erro (linhas 9 e 10), ou mesmo que a Marta faça um comentário lateral (linha 12), não é suposto alguém que não a inquiridora dê pistas sobre a solução da adivinha. Neste sentido, quem possui o livro tem, pelo menos, o poder de inquirir e de gerir o acesso dos outros a este, controlando a situação.

O livro "Adivinha, adivinha", como se referiu, e por comparação com os outros livros de adivinhas da sala, é o livro das adivinhas difíceis. A Catarina formula as adivinhas com base numa selecção de imagens $^{28}$ e com uma pergunta que torna óbvia a resposta. A fórmula de introdução da tradição oral "Qual é a coisa qual é ela", abreviada para "Qual é a coisa que”, serve de base à formulação também oral da adivinha que é lida não no texto mas na imagem. Assim, para a imagem de um botão a Catarina pergunta “Qual é a coisa que nós cosemos?” (linha 7) ${ }^{29}$. No entanto, o modo como a Catarina formula as adivinhas gera um pequeno tropeço quando induz, a partir da imagem de um rebuçado, a resposta errada por um lapso literácito ou de analogia ${ }^{30}$ (linhas 9 e 10). Ao dizer "Começa por 'b'..." a Catarina refere-se ou a boca, o seu enunciado31, ou a bombom e não a

28 As adivinhas formuladas são baseadas em imagens salteadas entre as páginas 28 e 37 do livro.

29 No texto a adivinha correspondente à imagem do botão é "Qual é a coisa, qual é ela, mal entra em casa põe-se à janela?"

$30 \mathrm{~A}$ imagem pode ser interpretada como rebuçado ou como bombom. Trata-se de um pequeno paralelepípedo achatado, embrulhado em papel de riscas torcido em ambos os extremos.

31 Neste caso, o enunciado da adivinha é completamente da iniciativa da criança, pois à imagem do rebuçado não corresponde qualquer adivinha formulada no texto do livro. 
rebuçado, a resposta que ela própria dá como correcta. Pelo conhecimento que temos da Catarina, estamos em crer que se trata, efectivamente, de um lapso e não de um erro (ou incapacidade de identificação da letra inicial da palavra rebuçado). Mas o que é interessante é o modo como a Catarina reformula a pista para a solução: “Qual é a coisa que nós temos na boca com os dentes a cair?” (linhas 9 e 10). Ao juntar sincronicamente causa e efeito - o rebuçado tem-se (põe-se) na boca e como consequência os dentes ficam estragados e um dia caem - numa espécie de sincretismo em que passado e futuro se tornam síncronos, a Catarina encontra uma estratégia de ultrapassagem da formulação da adivinha uma vez que não dispõe de um modelo verbal a reproduzir. A Catarina produz, neste caso, em primeira mão, uma leitura das imagens reproduzindo-a sob a forma tradicional da cultura oral: primeiro a fórmula de introdução, que se encontra enunciada no texto da adivinha anterior e que constitui uma das formas mais comuns na adivinha tradicional, seguida de um corpo central que, ainda que verosimilmente causado por um lapso, resulta numa construção enigmática em que há dois elementos básicos (...): um fornece elementos para a solução, o outro desconstrói a ordem aparentemente criada (Nogueira, 2004: 2), neste caso por anacronismo dos dois elementos.

A confusão na formulação da adivinha tem por consequência a intervenção da Marta, que faz uma chamada à realidade ${ }^{32}$, "Achas que a boca cai?" (linha 12), indignada com a falta de sensatez da resposta da Margarida, "Boca!" (linha 11). Ainda assim, a Margarida não perde a face porque a Catarina aceita a sua falha (não se pode afirmar se por reconhecer a sua própria) e prossegue com "naturalidade" a situação, não valorizando tacitamente nem a intervenção da Marta nem o erro da Margarida (linhas 13 e 14).

No entanto, uma segunda falha da Margarida ser-lhe-á fatal, quebrando, ela própria, a sua díada com a Catarina, num modo típico de salvar a face (Goffman, 1974). Confiante, passa para a frente da Marta e aceita ser sua interlocutora num novo jogo de adivinhas em torno do livro da Marta, "Animais e muito mais...".

Deste momento interactivo entre a Catarina, a Margarida, a Marta e a Susana relevam as relações diferenciadas entre as quatro meninas. A Catarina liderando, a Margarida aceitando o jogo mas com alguma vontade de liderar também (daí a sua retirada da díada inicial e o modo como a seguir toma o pulso à situação, como se verá adiante, na linha 87), a Marta numa participação discreta, nem por isso não assertiva (linha 12) e a Susana com uma participação recusada implicitamente na acção da Catarina (linha 28) e da Margarida (linha 33), não aceitando que ela responda por si. Diga-se que a

32 A propósito cf. Sarmento, 2004: 26: "Na verdade, a dicotomia realidade-fantasia é demasiado frágil para denotar o processo de imbricação entre dois universos de referência que nas culturas infantis efectivamente se encontram associados".

33 Este era um procedimento também usual na prática da educadora, ao ignorar algumas intervençôes das crianças para prosseguir a leitura ou manter o seu ritmo. 
Susana é, no grupo, a "chorona", a "fiteira" e ela própria reforça um estatuto um pouco marginal e mesmo inferior, autorepresentando-se como "princesa" mas "pobre",

Retomando sempre a fórmula de introdução, o corpo central da adivinha constitui frequentemente, ainda que conhecido previamente, uma surpresa pelo modo sempre potencialmente renovado da sua formulação. Fruto da preeminência da oralidade, as adivinhas reproduzem-se interpretativamente sobre as imagens, num grau de flexibilidade de enunciado virtualmente infinito. Paralelamente, em torno da rotina há sempre espaço para o inesperado, o nonsense, o suspense, o segredo. É esta dimensão da adivinha como brinquedo verbal (Topa, 1998: 63) que as crianças exploram ad infinitum na sua interacção em torno do livro de adivinhas. Trata-se aqui de uma manifestação inequívoca do grau de autonomia que as culturas infantis ganham em relação ao referente adulto que reproduzem interpretativamente. Assim, o jogo das adivinhas, com base no livro ilustrado, desenvolve-se segundo três eixos de estabilidade i) o aspecto de rotina da interacção; ii) as regras instituintes da acção; e iii) os princípios que estruturam a acção (cf. Ferreira, 2004b: 64). É esta estabilidade intrínseca à rotina, neste caso o jogo das adivinhas, que permite as variações a que se assiste no decurso de cada momento de um episódio interactivo. É este tempo recursivo, continuamente reinvestido de novas possibilidades (Sarmento, 2004) que aceita repetições sucessivas em que, se a estrutura se mantém, os detalhes se refinam e as interacções se intensificam. Os pequenos desvios, os “erros", os lapsos - como aconteceu na adivinha do rebuçado - são elementos que se incorporam na acção como elemento inesperado, e a reconfiguram como rotina, num desvio potenciador da mobilização de novos saberes e inesperadas interacções. Todavia, as regras e os princípios que a estruturam asseguram a continuidade da acção, que de outro modo poderia ser ameaçada e consequentemente interrompida, quebrando-se os elos de comunicação previamente estabelecidos entre as duas crianças que jogam o jogo, a Catarina e a Margarida. É o que acontece, quando a Margarida dotada de poder de decisão, porque da sua aceitação depende a continuidade do jogo, quebra a díada interactiva com a Catarina. Mais tarde, no entanto, a Margarida retoma a sua díada interactiva com a Catarina, desta vez liderando ela a interacção.

34 "O meu quarto é de princesa. O meu papá quer que eu tenha tudo do melhor. Mesmo sendo pobre..." (diário de campo, 12.6.2007) De referir ainda que as habilitações académicas dos pais da Susana estão perfeitamente dentro da média das do grupo de pares, o que à partida não a marginalizaria socialmente. Todavia, parece ser o discurso do próprio pai que induz essa marginalização assumida pela Susana e que a reconfigura na personagem complexa da "princesa-chorona". A Susana e a Catarina são muito amigas (o que é visível nas suas interacções e confirmado pela Rita, a educadora), mas a sua relação de amizade é ambígua. A Catarina domina sistematicamente as situações e alia-se muitas vezes às outras meninas, pondo de lado a Susana. As atitudes de vitimização da Susana não são bem-vindas no grupo e concorrem para a sua definição como elemento de estatuto frágil nas interacçōes entre pares. 


\begin{tabular}{|c|c|}
\hline 85 & $(\ldots)$ \\
\hline 86 & Margarida: (remexendo os livros) 'Pera aí... 'tou a escolher outra. (Pega no"Adivinha, \\
\hline 87 & adivinha" e senta-se sem abrir o livro) Qual é a coisa qual é ela que mal chega a casa \\
\hline 88 & põe-se logo à janela? Catarina! \\
\hline 89 & Catarina: Botão! \\
\hline 90 & Margarida: Muito bem! \\
\hline 91 & A Marta e a Margarida folheiam o livro, sentadas no sofá. A Catarina senta-se em frente \\
\hline 92 & a elas. \\
\hline 93 & Catarina: Anda lá, Margarida! \\
\hline 94 & Margarida: (mantendo o livro encostado ao peito) Qual é a coisa qual é ela que tem o pé \\
\hline 95 & e é venenoso? \\
\hline 96 & Catarina: Cogumelo! \\
\hline 97 & Margarida: Muito bem! (espreitando o livro) Qual é a coisa que dá luz à noite e há em \\
\hline 98 & todos os países? \\
\hline 99 & Catarina: Não sei qual é a que tu 'tás a fazer... \\
\hline 100 & Margarida: (virando o livro para a Catarina) 'Tou a fazer estas todas... (folheando para \\
\hline 101 & trás) Vamos voltar atrás... \\
\hline 102 & (...) [A Catarina senta-se ao lado da Margarida] \\
\hline 103 & Catarina: Esta? (apontando de novo) \\
\hline 104 & Margarida: Não (avançando a página) Esta! (parando na folha de rosto e encostando o \\
\hline 105 & livro ao peito) Qual é a coisa qual é ela que mal chega a casa... (ri) é outra vez esta! \\
\hline 106 & (fechando o livro e referindo-se à adivinha da capa) Qual é a coisa qual é ela que tem \\
\hline 107 & ouro lá dentro? (mantendo o livro fechado contra o peito) \\
\hline 108 & Guilherme: (do tapete) Sol! \\
\hline 109 & Margarida: Não é fogo, ouro! \\
\hline 110 & Guilherme: Monte! \\
\hline III & Margarida: Achas que o monte tem ouro lá dentro? (abrindo o livro e folheando-o) Onde \\
\hline 112 & é que ela 'tá? (parando) Tesouro! \\
\hline
\end{tabular}


II4 Catarina: Nós queremos ver livros...

I 5 Margarida: Qual é a coisa que tem oito pernas? (com o livro encostado ao peito)

II6 Catarina: Polvo!

II7 Margarida: Será? (virando o livro para a Catarina) É, sim senhor! (passando o livro à

\section{$118 \quad$ Catarina}

I19 [A Catarina folheia o livro e a Margarida aproxima-se dela ... ]

120 Catarina: (com o livro encostado ao peito) Qual é a coisa qual é ela que tem pintas e é

I21 amarela?

122 Margarida: Girafa!

I23 Catarina: Girafinha!

I24 Margarida: Queres vir fazer o coiso do Manel? (referindo-se ao puzzle)

125 Catarina: Não.

I26 A Margarida levanta-se e sai da biblioteca.

I27 Catarina: Agora já sei as adivinhas! (pousa o livro e sai)

128 São 9 h55m

Esta nova díada constituída pela Margarida e pela Catarina mais não é que uma variação de retorno ao início do episódio interactivo. Apossando-se do livro "Adivinha, adivinha", objecto simbólico da díada inicial, a Margarida lança o jogo com a adivinha que figura na capa do livro, reproduzindo quase ipsis verbis a formulação escrita da pergunta ${ }^{35}$. A aceitação da Catarina como respondente determina o início da interacção entre as duas. A Marta regressa à sua posição inicial de participante passiva, agora destituída do objecto simbólico que lhe potenciava a acção, o livro, e limita-se a assistir ao desenrolar do jogo entre as outras duas crianças. A Catarina não permite, ainda assim, que os princípios estruturantes e as regras da acção sejam quebrados. O jogo das adivinhas, pautado por uma repetição de perguntas e respostas que se sucedem a um ritmo rápido, não admite ser perturbado por atrasos nem da respondente nem da inquiridora. “Anda lá, Margarida!” (linha 93) é a chamada de atenção da Catarina à sua interlocutora que parece dispersar-se nas páginas do livro, 
na companhia da Marta. Ora, talvez o reparo da Catarina seja ainda uma estratégia de legitimamente afastar a Marta da sua interacção com a Margarida (não podemos esquecer-nos que a Marta foi cúmplice da Margarida quando esta, por sua iniciativa, quebrou a díada com a Catarina, o que pode simbolicamente mantê-la como rival). A Margarida responde positivamente à chamada de atenção por parte da Catarina e formula uma nova adivinha baseada na imagem de um cogumelo, que figura na página final do livro e à qual não corresponde qualquer adivinha escrita. A fórmula de introdução reproduzida com exactidão "Qual é a coisa qual é ela" (linha 94) confere à adivinha formulada pela Margarida uma verosimilhança que poderia levar o observador desinformado a crer que se tratava da reprodução da adivinha escrita. Só o completo e detalhado conhecimento do livro de adivinhas nos permite aceder aos significados reais da acção das crianças. Do mesmo modo, a adivinha seguinte (linha 96), baseada na imagem de um farol, na página contígua, não tem referente escrito.

Ao confessar "Não sei qual é a que tu 'tás a fazer..." (linha 98), a Catarina desvela um dos princípios estruturantes da acção: a sequência das adivinhas (mais exactamente das imagens, neste caso) deve ser do conhecimento da respondente, sob pena do jogo encalhar na incapacidade de resposta. No modo como responde ao apelo da Catarina, a Margarida revela o conhecimento destes princípios e decide, então recomeçar o jogo (naquela recursividade temporal própria da acção da crianças) voltando ao início do livro. Este reinício do jogo depende, no entanto, da aprovação e cumplicidade da Catarina e a Margarida vai folheando o livro até chegar à capa. Aqui, a Margarida confirma ela própria, com o seu riso, o gozo da repetição. É na descoberta deste nexo entre o passado da brincadeira que se repete e o futuro da descoberta que se incorpora de novo (Sarmento, 2004: 28) que a interacção se intensifica e os laços de cumplicidade se reforçam. A simples sugestão da adivinha da capa inaugura o reinício do jogo.

A Margarida prossegue, então, recomeçando o jogo de uma forma surpreendente. Sem abrir o livro, ela enuncia uma nova adivinha, baseada exclusivamente na sua memória “Qual é a coisa qual é ela que tem ouro lá dentro?”36 (linha 112) e só depois da resposta inusitada do Guilherme procura a página onde figura a imagem “Onde é que ela 'tá?” (linha 117) para afirmar a resposta correcta. Entretanto, verifica-se aqui um confronto de saberes entre a Margarida e o Guilherme, com a Margarida a forçar a resposta pretendida, mesmo contrariando o conhecimento correcto expresso pelo Guilherme. A ela, não lhe interessa que ele saiba que o ouro se encontra nos montes, interessalhe jogar às adivinhas e isso passa, apenas, por responder correctamente à pergunta formulada. A Catarina confirma verbalmente este facto, quando diz "Nós queremos ver livros..." (linha 120), reclamando a preeminência do jogo em detrimento da expressão de saberes e afirmando-se, a ela e à 
Margarida como uma equipa (Goffman, 1959/1993) e, consequentemente, remetendo o Guilherme para a posição de mera audiência. A Margarida aprova tacitamente a intervenção da Catarina prosseguindo o jogo com mais uma adivinha e uma nova variante se introduz na rotina. Perante a resposta acertada da Catarina, a Margarida cria o efeito de suspense, tão tipicamente usado pelo adulto, pondo em dúvida a resposta da sua interlocutora "Será?" e depois revelando-lhe a imagem e a confirmação da sua resposta com um aprovador “É, sim senhor!" (linha 123). Como uma espécie de deferência (Goffman, 1974) para com a sua companheira de jogo a Margarida passa o livro à Catarina, partilhando assim com ela o poder de questionar. Esta atitude, já ocorrida anteriormente entre a Marta e a Margarida, parece reforçar a cumplicidade na díada. A partilha do livro, objecto que simboliza o poder de questionar, é passado como um testemunho de confiança e amizade que visa fortalecer a relação entre as duas meninas e permitir subtilmente à Margarida apropriar-se do domínio da situação. É que para jogar o jogo das adivinhas é preciso que a Margarida esteja disposta a responder às perguntas da Catarina. O poder de perguntar é um poder relativo, dependente da Margarida. Ora, à Margarida interessa-lhe mudar o curso da interacção e é precisamente por fazer parte da equipa que tem a possibilidade de causar este género de perturbações (Goffman, 1959/1993: 104). Colocando-se estrategicamente ao lado da Catarina, a Margarida consegue atingir o seu objectivo: propor a nova situação “Queres vir fazer o coiso do Manel?” (linha 132), sem que a recusa da Catarina implique a sua não concretização. Pelo contrário, a recusa da Catarina forçá-la-á a seguila. Imbuída estrategicamente de um objectivo pessoal, a Margarida não cederá e abandonará o espaço interactivo com a legitimidade que ser elemento da equipa lhe confere (linha 133). A Catarina, após uma declaração "vitoriosa”" (linha 134) que exprime verbalmente o objectivo profundo da sua acção, dominar as adivinhas difíceis para dominar no grupo, segue a Margarida, pondo assim fim a este episódio interactivo.

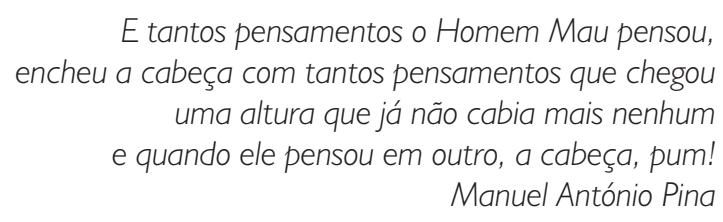




\section{Considerações finais}

Procurando romper com a ideia superficial de que enquanto as crianças vêem livros apenas "vêem livros", a análise deste episódio interactivo entre crianças de JI põe em evidência a complexidade de acções e interacções que estão em jogo numa situação em que, na biblioteca, dir-seia, as crianças estão simplesmente a ver livros. As negociações de sentido e poder implicadas numa situação desta natureza relevam da importância do livro como objecto simbólico de poder, que confere aos actores sociais a possibilidade de alterar o curso dos acontecimentos (cf. Giddens, 1976, in Chazel, 192/1995: 197) e de fazer triunfar no seio de uma relação social a sua própria vontade (Weber, 1971: 56). Por outro lado, no decorrer das interacções entre as crianças assiste-se a uma continuidade das práticas institucionais de uso do livro ilustrado num modo de reprodução interpretativa (Corsaro, 1985, 1993, 2002, 2005, Corsaro \& Miller, 1992) que desvela as concepções adultas sobre o uso dos livros e as suas ressignificações por parte das crianças.

A etnografia, na sua componente de observação e escuta do outro, revela-se aqui uma metodologia capaz de desvendar os significados profundos das interacções entre crianças no uso do livro ilustrado. Tendo por base um conhecimento das rotinas do grupo e das práticas sociais instituídas, assim como de cada um dos actores sociais, torna-se possível, por análise de conteúdo das notas de campo, dar conta i) da agência das crianças na construção de uma identidade social no grupo; ii) dos modos de ressignificação simbólica dos livros ilustrados nas relações de poder entre crianças; iii) dos modos de configuração e reconfiguração das relações de identidade e posição dos actores no grupo de pares.

Fundamental também, no âmbito desta problemática, é o conhecimento profundo dos livros em uso. Só uma análise crítica de textos e imagens e das suas relações permite estabelecer as necessárias e desejáveis relações entre o livro nas suas múltiplas dimensões e as acções sociais tecidas em seu torno. É indispensável conhecer os textos, conhecer as imagens, conhecer as relações directas ou indirectas que se estabelecem entre tex to verbal e texto visual. É desejável ainda um conhecimento teórico dos géneros literários e das suas sub-categorias para que se possam estabelecer as relações correctas entre a produção adulta registada sob a forma de livro e a (re)produção infantil expressa em discursos verbais e da corporeidade.

Numa perspectiva metodológica crítica e reflexiva, enquadrada nos pressupostos teóricos da Sociologia da Infância, o trabalho etnográfico permite romper com as ideias feitas de que o que os adultos pensam sobre os usos do livro ilustrado equivale à sua prática efectiva por parte das crianças. Nomeadamente, no que refere às crianças do JI, é urgente reconfigurar as concepções de infância que definem as crianças pequenas (ditas não leitoras) como actores sociais incapazes de ler o mundo. $\mathrm{O}$ 
facto de não descodificarem o código escrito e não possuírem as competências de literacia entendidas necessárias para o acesso à informação e ao direito de participação social, não significa que as crianças não possuam competências que as tornam capazes de interacções sociais de uma grande complexidade e que reproduzem interpretativamente as relações sociais dos adultos e os seus modos de uso do material impresso. O modo como as crianças utilizam os livros ilustrados, em situação de livre iniciativa e de relativa autonomia face ao adulto que controla o uso institucional dos livros, revela como as práticas sociais instituídas e os valores simbólicos atribuídos aos objectos da produção cultural da sociedade letrada são ressignificados nas interacções no interior do grupo de pares. O livro-talismã confere ao seu portador um estatuto social, no grupo, de superioridade e poder. Mais ainda, a qualidade do talismã - quando as diferenças entre a acessibilidade aos enigmas são identificadas e expressas pelas próprias crianças - determina também a posição do seu portador no grupo. Cada livro ocupa também, ao que parece, um lugar próprio na hierarquia simbólica da sua categoria de objecto cultural. O valor transaccional de um livro de adivinhas "difíceis" é maior do que o de um livro de adivinhas "fáceis". Enquanto "moeda de troca" o livro de adivinhas difíceis vale mais, isto é, permite transacções de significado ao nível das estruturas profundas, sobretudo quando utilizado pelos actores prestigiados do grupo.

Concluindo, pode dizer-se que neste contexto, especificamente, as regras social e pedagogicamente instituídas de uso do livro no JI, ainda que não explicitamente referidas em algum documento mas assumidas como prática corrente nestas instituições (como sejam, a existência de um espaço de biblioteca com regras de uso próprias, a instituição de uma "hora do conto" ou, neste caso particular, "momento de leitura partilhada pelo grupo") foram adoptadas pela educadora de um modo circunstancial. Ou seja, a reificação do livro na sala do JI quer pela sua presença destacada quer pelo seu uso sistemático não concorriam para uma definição dos pressupostos pedagógicos inerentes a esta prática. Trata-se, pois, parece-nos de uma aceitação não reflexiva das práticas instituídas da educação de infância e de um uso espontâneo e não pedagógico (por conseguinte, não racional ou crítico) do livro. A acção adulta, aqui, vem de certo modo, assemelhar-se à acção das crianças, com um uso do livro ao sabor do momento, de consequências inesperadas e imprevisíveis ${ }^{37}$. Assim, o livro, nesta sala, colocado em lugar de destaque no espaço e discurso adultos era objecto mais de interacções sociais entre adulto e crianças do que de acções pedagógicas. Eleitos como objectos simbólicos, por ambas as partes, os livros ilustrados serviam relações sociais, jogando-se a identidade do adulto na fragilidade do seu (des)conhecimento dos objectos. 
Não obstante, todo um currículo oculto assoma da observação das práticas induzidas de uso do livro ilustrado por parte das crianças. As competências sociais e de literacia emergentes neste contexto, em que o uso do livro é, ainda assim, definido por prerrogativas adultas, tornam-se visíveis ao olhar e à escuta da etnógrafa, que de dentro procura desafiar os grandes mitos da infância que ainda hoje vigoram ${ }^{38}$. Reconfigurar as crianças à luz dos pressupostos da Sociologia da Infância é possível usando os livros ilustrados, objectos culturais e simbólicos da produção adulta como analisadores do fenómeno da infância, enquanto processo inter e intrageracional onde ocorrem transacções de sentido em que a intersubjectividade só se torna visível de dentro para fora. $\mathrm{Na}$ continuação de um virar do avesso (Ferreira, 2004ª 2004b) do quotidiano institucional das crianças do JI, este artigo é apenas porto de partida para uma longa viagem pelo mundo dos livros para e da infância.

Pensamos que, ao redefinir o livro de adivinhas como objecto de uso por parte das crianças, estaremos a contribuir para a consciencialização da necessidade de i) reavaliar o papel do livro no quotidiano dos tempos e espaços do JI; ii) reavaliar as práticas de uso do livro ilustrado com crianças, em contexto institucional; iii) reconfigurar o livro como objecto cultural produtor de sentidos intersubjectivos; iv) reconfigurar o livro ilustrado como objecto de transacções sociais e apropriações culturais por parte das crianças que o usam, no grupo de pares; e, finalmente, v) rever as concepções de infância que presidem à escolha e selecção dos materiais impressos que são disponibilizados para uso das crianças.

Num plano mais aproximado dos teóricos da literatura para a infância, esperamos estar a questionar noções como as de para-literatura ou cânone literário, que, em nosso entender, deverão ser definidas de baixo para cima e não de cima para baixo, isto é, a partir das práticas de uso pelas crianças e não dos (pré)conceitos exclusivamente adultos do que é e para que serve o livro ilustrado. A qualidade do livro para crianças residirá mais, estamos em crer, na qualidade e quantidade de acções e interacções que for capaz de gerar do que em aspectos mais ou menos formais definidos de acordo com os sistemas de avaliação dos adultos da cultura que eles próprios produzem. Será, pois, do cruzamento entre a qualidade do livro enquanto gerador de práticas sociais, quer entre crianças quer entre crianças e adultos, e a sua qualidade enquanto objecto material (cultural, artístico) concreto que surgirão os princípios orientadores de uma avaliação justa da qualidade dos livros para crianças.

38 A saber, i) as crianças como seres em deficit e objectos de uma socialização passiva; ii) a socialização como processo vertical e unívoco de que os adultos são os mandatários exclusivos; iii) o brincar como uma actividade natural e espontânea das crianças, porta-estandarte da sua condição menor; iv) o grupo de pares como grupo homogéneo, onde as relações sociais não se desigualam (cf. Ferreira, 2004a:96; Ferreira, 2004b: 15) 
Referências

BOUDON, Raymond (1992) Tratado de Sociologia, Edições Asa, Porto, 1995.

CHAZEL, François (1992) "Poder" in Boudon, Raymond (1992) Tratado de Sociologia, Edições Asa, Porto, 1995, 195-224.

LEONARD, Diana (1991) "Persons in Their Own Right: Children And Sociology in the UK" in Chrisholm, L., Büchner, P., Krüger, H. H. \& Brown, Ph. (1990) Childhood, Youth and Social Change - a comparative perspective, The Falmer Press, London, 58-71.

COOK-GUMPERZ, J. \& CORSARO W. (1986) "Introduction" in Corsaro, W; Cook-Gumperz, J; Streeck, J. (eds) Children's Worlds and Children's Language, Mouton de Gruyter, Berlim, 1-11.

CORSARO, William (1997) The Sociology of Childhood, Pine Forge Press, 2nd edition (2005).

CORSARO, William A. (2002) "A reprodução interpretativa no brincar ao «faz-de-conta» das crianças", Educação, Sociedade e Culturas, no 17, Revista da Associação de Sociologia e Antropologia da Educação, Edições Afrontamento, Porto, 113-134.

CORSARO, William (1993) “Interpretive reproduction in children's role play", Childhood, 1, 6474.

CORSARO, W. \& MILLER, P. J (eds) (1992) Interpretive Approaches to Children's Socialization, Jossey-Bass Publishers, San Francisco.

CORSARO, William (1985) Friendship and Peer Culture in the Early Years, Ablex Publishing, Westport, Connecicut.

CORSARO, William (1979a) “'We're friends, right?': Children's use of access rituals in a nursery school”, Language and Society, 8, 315-336.

CORSARO, William (1979b) "Young Children's Conception of Status and Role” in Sociology of Education, Vol. 52, Issue 1, Jan, 49-59.

CORSARO, W. \& STREECK, J. (1986) “Studying Children's Worlds: Methodological Issues” in Corsaro, W; Cook-Gumperz, J; Streeck, J. (eds) Children's Worlds and Children's Language, Mouton de Gruyter, Berlim, 13-35.

COSER, Lewis A. (1977) «The significance of Simmel's Work» in Coser, Lewis A. Masters of Sociological Thought: Ideas in Historical and Social Conext, second edition, New York, Harcourt Brace Jovanovich.

DENZIN, Norman K., LINCOLN, Yvonna (eds.) (1998) Strategies of Qualitative Inquiry, SAGE Publications, California.

FERREIRA, Manuela (2004a) «A gente gosta é de brincar com os outros meninos!» - Relações Sociais entre Crianças num Jardim de Infância, Edições Afrontamento, Biblioteca das Ciências Sociais, Porto.

FERREIRA, Manuela (2004b) "Do «avesso » do brincar ou... as relações entre pares..." in Sarmento, M. J., Cesiara (org) (2004) Crianças e Miúdos - perspectivas sociopedagógicas da infância e da educação, Edições Asa, Porto, 55-104.

GARCÍA, M. Rizo (2006) "George Simmel, Sociabilidad e Interacción. Aportes a la Ciencia de la Comunicación”, Cinta de Moebio, Deciembre, n 027, Universidad de Chile, Santiago, Chile, 4360. 
GARFINKEL, Harold (1967) Studies in Ethnomethodology, Polity Press, Cambridge, 1999.

GEERTZ, Clifford (1973) The Interpretation of Culture, Basic Books, New York, 2000

GOFFMAN, Erving (1959) A Apresentação do Eu na Vida de Todos os Dias, Relógio d'Água, Lisboa, 1993.

GOFFMAN, Erving (1974) Les rites d'interaction, Les Éditions de Minuit, Paris.

GUMPERZ, J; STREECK, J. (eds) Children's Worlds and Children's Language, Mouton de Gruyter, Berlim, 231-251.

HUNT, Peter (2004) "Children's literature and childhood" in Kehily, Mary Jane (ed) An Introduction to Childhood Studies, Open University Press, Berkshire, 39-56.

JAMES, A., JENKS, C. \& PROUT, A. (1998) Theorizing Childhood, Polity Press, Cambridge.

JAMES, Allison \& JAMES, Adrian L. (2004) Constructing Childhood. Theory, Policy and Social Practice, Palgrave, MacMillan, London.

MAIA, Gil (2003) "As capitais da ilustração", No Branco do Sul as Cores dos Livros, $5^{\circ}$

Encontro sobre Literatura para Crianças e Jovens, Beja, 20 e 21 de Fevereiro de 2003 - ACTAS, Caminho, Lisboa, 2005, 113-146.

NOGUEIRA, Carlos (2004) "Para uma teoria da adivinha tradicional portuguesa", Revista de Literaturas Populares, México, Facultad de Filosofia y Letras, Universidad Nacional Autónoma de México, año IV, n²2, Julio-Deciembre de 2004, 328-339 [disponível em www.casadaleitura.org].

PEREIRA, Virgílio B. (2005) Classes e Culturas de Classe das Famílias Portuenses - Classes Sociais e «Modalidades de Estilização da Vida» na cidade do Porto, Edições Afrontamento, Porto.

SARMENTO, M. J. (2004) "As culturas da infância na encruzilhada da segunda modernidade" in Sarmento, M. J., Cesiara (org) (2004) Crianças e Miúdos - perspectivas sociopedagógicas da infância e da educação, Edições Asa, Porto, 9-34.

TOPA, Francisco (1998) Olhares sobre a Literatura Infantil - Aquilino, Agustina, conto popular, adivinhas e outras rimas, Edição do Autor, Porto.

TORRADO, António (2002) Da Escola sem Sentido à Escola dos Sentidos, Caminho, Cadernos O Professor, Lisboa ( $3^{\text {a }}$ edição).

WEBER, Max (1970) Conceitos Sociológicos Fundamentais, Edições 70, Lisboa.

WEBER, Max (s/d) Fundamentos da Sociologia, Rés Editora, Porto, 2ª edição. 